\title{
Impact of Organizational Culture on Employee Performance and Productivity: A Case Study of Telecommunication Sector in Bangladesh
}

\author{
Mohammad Jasim Uddin ${ }^{1}$, Rumana Huq Luva ${ }^{2} \&$ Saad Md. Maroof Hossian ${ }^{1}$ \\ ${ }^{1}$ School of Business, North South University, Bashundhara, Dhaka, Bangladesh \\ ${ }^{2}$ Centre for Strategic Policy and Research, Dhaka, Bangladesh \\ Correspondence: Mohammad Jasim Uddin, Lecturer, School of Business, North South University, Room NAC \\ 755, Block B, Plot 15, Bashundhara, Dhaka 1229, Bangladesh. Tel: 88-885-2000 Ext. 1739. E-mail: \\ uddinmj@gmail.com
}

\author{
Received: August 17, 2012 Accepted: December 12, 2012 Online Published: December 22, 2012 \\ doi:10.5539/ijbm.v8n2p63 URL: http://dx.doi.org/10.5539/ijbm.v8n2p63
}

\begin{abstract}
Today's organizational is predominantly dynamic that pose enormous opportunities and challenges to the corporate practitioners and policy makers. Understanding such dynamism is very crucial to pursue the organizational strategic objectives. The primary aim of this paper is to examine the impact of organizational culture on employee performance and productivity from the perspectives of multinational companies operating especially under the telecommunication sector of Bangladesh in South Asia. The paper has applied qualitative methodology focusing on a case study of Grameenphone (GP) (a subsidiary of Teleron in Norway), the leading telecommunication based subsidairy in Bangladesh. The paper argues that organizational culture significantly influences employee performance and productivity in the dynamic emerging context.
\end{abstract}

Keywords: culture, performance, productivity, telecommunication

\section{Introduction}

There has been significant research in the literature to explore the impact of organizational culture on employee performance and productivity. For instance, scholars (Hofstede, 1980; Ouchi, 1981; Hofstede \& Bond, 1988; Kotter and Heskett, 1992; Magee, 2002) claim that organizational culture could be used for measuring economic performance of an organization. However, organizational excellences could be varied since cultural traits differ from organization to organization and certain cultural traits could be source of competitive advantages through causal ambiguity (Barney, 1991 and Peters and Waterman, 1982). The world is changing rapidly and the level of employee expectation and satisfaction also change accordingly. Organizational culture adapts overtime to cope up with such dynamic changes and meet the varying demand of employee expectations and satisfactions. Therefore a supportive culture as pointed out by Ritchie (2000) is considered as a motivational instrument which promotes the employees to perform smoothly and ensures better productivity (Ritchie, 2000). Research has been carried out on various issues of organizational culture, for example, organizational culture types (Tharp, 2009) emphasize the stages of culture across the organization whereas organizational psychology (Schein, 1990) focuses on how culture makes an impact on employees' psychology and performance. These two issues of organizational culture set up equilibrium where an organization can achieve its maximum level of effectiveness and efficiency (Deem, Barnes, Segal \& Preziosi, 2000) that shows the link between organizational culture and employee performance. Notwithstanding the organizational culture and employee performance have been studied over the past decades and considered as an immersed topic for achieving organizational excellences, there is no empirical research conducted on the effects of organizational culture on employee performance particularly from emerging country perspective like Bangladesh. Since multinational corporations have been extending their operations in emerging countries, this would be critical to examine how organizational culture affects employee performance and productivity. Thus the main aim of the paper is to examine the impacts of organizational culture on employee performance and productivity in the context of Bangladesh. The paper seeks to answer the following research questions: (1) How organizational culture affects employee performance and productivity. (2) Whether organizational culture is a determinant of higher employee performance and productivity? If so, why? 
Which aspects of organizational culture are important to employees in determining their level of work performance?

\section{Literature Review}

Organizational culture is conceptualized as shared beliefs and values within the organization that helps to shape the behavior patterns of employees (Kotter and Heskett, 1992). Gordon and Cummins (1979) define organization culture as the drive that recognizes the efforts and contributions of the organizational members and provides holistic understanding of what and how is to be achieved, how goals are interrelated, and how each employee could attain goals. Hosftede (1980: 25) summarizes organization culture as collective process of the mind that differentiates the members of one group from the other one. Thus the above concept asserts that organizational culture could be the means of keeping employees in line and exhilarating them towards organizational objectives. Early organization behavior researchers (Peters and Waterman, 1982; Deal and Kennedy, 1982; and Pascale and Athos, 1981) find the unambiguous links between culture and organizational performance. These cultural values are consistent with organizational chosen strategies that led to successful organizations. Although the relationships between organizational culture and employee performance have been widely accepted, some researchers (Willmott, 1993; Legge, 1994; and Ogbonna, 1993) raise concerns about the relations. Thus Gordon and DiTomaso (1992) and Denison (1990) argue that culture characteristics might affect performance but restricted or conditioned to the specific context. They further argue that culture may lead to higher performance if it fits with changes of environmental factors within the context. Recently, researchers argue that cultural traits cannot be copied and therefore it could be source of organizational sustainability. Resource-based view (Barney, 1986 and 1991) suggests that sustainability depends on the values, rarity and sustainability of the culture concerned. Overall, the aim of the literature review is to examine the existing research to explore the links between culture and performance.

Due to the subjective nature of culture, it could be challenging to precisely define the specifications of organizational culture. Despite no single theory is uniformly accepted, there is a general consent about organizational culture on being traditionally determined and socially structured that involves beliefs, behaviors, values and morals allied with different levels of the organization and incorporates to all aspects of organizational life (Pettigrew, 1990 and Hofstede, Neuijen, Ohauv and Sanders, 1990). The organizational culture is outlined by Schein (1990) as overall phenomenon of the organization such as natural settings, the rite and rituals, climate and values of the company. According to Martins and Terblanche (2003), culture is deeply associated with values and beliefs shared by personnel in an organization. Organizational culture relates the employees to organization's values, norms, stories, beliefs and principles and incorporates these assumptions into them as activity and behavioral set of standards. Klein et al. (1995) positioned organizational culture as the core of organization's activities which has aggregate impact on its overall effectiveness and the quality of its products and services. Schein (2004) defined organizational culture as a dynamic force within the organization which is revolving, engaging and interactive and it shaped up by the employees and managements gestures, behaviors and attitudes. Eariler scholars (Rossman, Corbett and Firestone, 1988; Schwartz and Davis, 1981; Cooke and Rousseau, 1988; Gordon and Di Tomaso, 1992; Schall, 1983; Schein, 1992; Rousseau, 1990) have explained culture as mutual experience which depends on the behavioral and societal activities.

Performance on the other hand refers to be the ability (both physical \& psychological) to execute a specific task in a specific manner that can be measured as high, medium or low in scale. The word 'performance' can be used to describe different aspects such as societal performance, organizational performance, employee performance, and individual performance etc. Researchers (Roe, 1999; Campbell, McCloy, Oppler, \& Sager, 1993; Campbell, 1990; Kanfer, 1990) tend to identify two dimensions of performance: an action dimension (i.e. behavioral aspect) and an outcome dimension (i.e. performance aspect). Here, the behavioral aspect of performance is assumed to be matched with work situation and job specifications. Then this selective behavioral aspect turns into a means of achieving organizational goals and objectives that is the outcome dimension or performance aspect. Although there is a range of behaviors that could be used for measuring performance, Motowidlo, Borman, \& Schmit (1997) emphasize judgmental and evaluative processes that take a great deal along with action itself while defining performance.

Early studies have indicated that there exist relationship between organizational culture and its performance. Magee (2002) in this very point argued that organizational culture is inherently connected to organizational practices; therefore organizational performance is conditional on organizational culture. According to Hellriegel \& Slocum (2009), organizational culture can enhance performance in a large scale if it can be understood that what sustains a culture. According to these authors the culture of an organization allows the employees to be acquainted with both the firm's history as well as current methods of operation and this specific detection 
endows the employees with guidance about expected and acceptable future organizational behaviors and norms. Some theoretical models assert that the effective human resource system of an organization is based on supporting values and then these systems, in turn, create a positive impact on employee attitudes and behavior, which facilitate organization's performance (Ferris et al., 1998). Mercer and Bilson (1985) also point out the correlation between organizational culture and employees' performance; and this employees' performance then translated into organizational outcomes such as customer satisfaction (Schmidt, Shull, and Schmitt, 2001).

Findings of research conducted by Renn and Vandenberd (1995) demonstrate a conceptual linkage between organizational culture and employee performanceMost organizations assert its performance as a dependent variable which seeks to recognize other independent variables that produce variations in its performance (March and Sutton, 1997). Martin and Siehl (1990) argue that organizational culture is theoretically related to performance and do have positive influence on it. Explaining the variation in performance of effectiveness, Bowen et al. (1989) in his relevant work highlighted that the role of culture is very vital in nurturing, sustaining and enhancing the performance of organizations. In addition to this, Kopelmal et al. (1990) clarified that cultural system of any organizations adds to the coordination of assignments and minimizes inefficiency employee efforts and firm's resources.

In order to meet the organizational objectives and achieve competitive advantages, all organizations are thriving to recruit highly performing individuals. On the other hand, individuals need supportive organizational culture to help them reach individual objectives. Therefore, an organization is a consciously coordinated system where characteristics of individuals, groups and organization interact with each other and effective interaction among them highly depends on organizational culture that shapes the individual performance (Kozlowski \& Klein, 2000) and in most of cases high performers are more appreciated and promoted than low performers (Cross et al., 2000). As a result evaluation of employee performance basically depends on the factors like performance appraisals, compensation, employee recognition, employee motivation, training and development, job security, flexible time system, organizational structure, employee satisfaction etc. But, this paper will concentrate on the basic factor or the roots of all above traits and that is the organizational culture.

There are numerous researchers who consider the importance of individual factors (i.e. ability and effort) to make a link between organizational culture and employee performance (Gardner \& Schermerhorn, 2004; Schermerthorn et al, 1990), it requires further investigation for better understanding and prediction of the relation between organizational culture and employee performance. According to Furnham and Gunter (1993), organizational culture functions as the internal integration and coordination between firms operations and its employees. Internal integration can be described as the societal interaction of new members with the existing ones, creating boundaries of the organization feelings of identity among personals and commitment to the organization. Shared system which forms the basis of communication and mutual understanding in organization is due to its culture and if the organizational culture fails to fulfill these functions at satisfactory level, the culture may have significant negative influence on the efficiency of the employees (Furnhum and Gunter, 1993).

A strong organizational culture supports adaptation and develops organization's employee performance by motivating employees toward a shared goal and objective; and finally shaping and channeling employees' behavior to that specific direction should be at the top of operational and functional strategies (Daft, 2010). A firm's mission reflects its ultimate long term objective which is accomplished by conducting integrated operational and behavioral activities. A firm's performance improves if it has a clear sense of purpose and commitment towards its mission. Successful and well performed organization defines its organizational goals as the report card of forthcoming (long term) future (Ohmae, 1982; Mintzberg, 1987; Hamel and Prahalad, 1994).

Along with others, shared value of employees is one of the basic components of organizational culture (Smit and Cronje, 1992; Hellreigel et al., 1998). Schein (1994) clarifies that value which is a set of social norms that define the rules or framework for social interaction and communication behaviors of society's members, is a reflection of causal cultural assumptions. Individuals who hold similar values may feel and interpret situations and events similarly (Meglino, Ravlin, \& Adkins, 1989) which can reduce uncertainty (Schein, 1985), role ambiguity, and conflict (Fisher and Gitelson, 1983), allow for the accurate prediction of other's behavior (Kluckhohn, 1951), and make successful interpersonal interactions more likely (Meglino et al. 1989). Academics and practitioners argue that the performance of an organization is dependent on the degree to which the values of the culture are widely shared (Peters and Waterman, 1982; Deal and Kennedy, 1982; Denison, 1990; Ouchi, 1981; Pascale and Athos, 1981 and Kotter and Heskett, 1992). Similarly, it is widely argued that shared and strongly held values enable management to predict employee reactions to certain strategic options and by reducing these values, the consequences maybe undesirable (Ogbonna, 1993). 
Deal (1999) defines organizational culture as values, beliefs and behaviors that differentiate one organization from another. Performance of any organization sets it apart from other organizations. The term performance is often used to describe everything from efficiency and effectiveness to improvement (Stannack, 1996) and previous literature studies obviously show evidence of positive relationship between organization culture and its performance. According to Hitt et al (2001), intangible resources are more likely than tangible resources to produce a competitive advantage. This theory was supported by Tecce (2000) that a firm's superior performance depends on its ability to defend and use the intangible assets it creates.

Satisfaction and positive attitude can be achieved through maintaining a positive organizational environment, such as by providing good communication, autonomy, participation, and mutual trust resulting superior employee performance (Argyris, 1964). The satisfaction and attitudes of the employees are important factors in determining their behaviors and responses at work and through these behaviors and responses, organizational effectiveness can be achieved. Thus the satisfaction and well being of employees can result in organizational effectiveness through silent productivity related behaviors of employs (McGregor, 1960).

Loyalty and commitment both interpret an emotional bonding between the individual and his or her cultural group and, as such, imply a willingness to put forth exertion and make sacrifices on behalf of that group (Druckman, 1994). However, whether loyalty and commitment are positively correlated with performance craved by the organization or not may depend on what values and norms the target cultural group holds regarding performance. O'Reilly (1989) suggests that employee's commitment to an organization will be more dedicated because they care about their organization's fate, and their caring heightens the power of organizational norms to control their behavior. From a different perspective culture shows its affect on performance by programming people to behave in such manners that more or less effective in terms of performance (Druckman, Singer and Cott, 1997).

Creativity and innovation also trigger the performance of employees and facilitated by organizational culture. Tushman and O'Reilly (1997) in this context stated that organizational culture lies at the heart of organizational norms that reflects the influence of organizational culture on creativity and innovation. Organizations Culture can play an important role in creating such an environment that enables learning and innovative response to challenges, competitive threats, or new opportunities. Thus, creating and influencing an adaptive culture is one of a manager's most important jobs (Daft, 2010).

According to socio-technical school (Emery \& Trist, 1960), organizational effectiveness depends on both the technical and social structure of the organization. Some social physiological structure may be superior to others for both employee satisfaction and productivity. Organizational effectiveness results when there is congruence between social and technical organizational dimension. Organizational productivity is achieved through employee satisfaction and attention to workers physical and emotional needs (Likert 1961). Akin and Hopelain have (1986) discussed about the crucial relationship between organizational culture, employee performance and productivity in their research on organizational culture and productivity; and introduced "culture of productivity" where they illustrate the components of a productive culture such as efficient people, job identification, teamwork, trust and support etc are determined by knowledge of job and the performance. Akin and Hopelain (1986) also argue that a culture of productivity is based on three basic structures and they are: legibility (clarity), coherence (integration of the elements of work) and open-endedness (adaptability to change).

Organizational culture is one of the most popular concepts in the field of management and organizational theory. This can be backed up by the abundance of theoretical concepts and perspective provided at current time (Martin, 1992) and organizational disciplines which utilize the concept (Harris and Ogbonna, 1999). Highly collective organizations emphasize group harmony, cooperation and reward for enhancing employee performance (Javidan \& Dastmalchian 2009). At the more operational level, the higher performing organizations have a management style that includes giving more freedom to their managers to take independent actions rather than simply following orders, to take reasonable risks and to openly discuss conflicts and constructive criticisms. High humane oriented organizations reward people who are fair, altruistic, friendly, generous, kind (Javidan \& Dastmalchian 2009). Managers get adequate information and support for decision making (decision-making structure) and they are given rewards and benefits based on performance that compare favorably to similar organizations (compensation). Finally, members of the higher performing organizations are well matched to their jobs and have sample opportunities for growth, development and career advancement within their organizations (human resource development).

Organizational culture is one of the very basic components of company's competitive advantage as well as to sustain performance. Northouse (2004) asserts that all the leaders have an agenda, a set of beliefs, proposals, 
issues, ideas and values which they wish to put in the table. These set of organizational culture are promoted by the leader and it has significant impact on the values exhibited by the organization (Carlson and Perewe, 1995; Schminke, Ambrose and Noel, 1997; Trevino, 1986). Competitive advantage which is the unique selling point of companies' performance is also supported and built up by the leaders and their inputs in organizational culture. Kotler and Keller (2006) define competitive advantage as company's ability to perform in one or more ways that competitors cannot and these cultural leaders achieve it by creating organizational culture to make employees believe that the substance of the performance is the most crucial (Schein, 2004).

Precise information and applicable knowledge always assist performance, whereas erroneous information and irrational knowledge are likely to do the opposite (Feldman and March, 1981; and Daft and Weick, 1984). Cultures also provide cognitive frameworks through which people interpret what they observe and experience and provide language and referents to use in communicating with others (Wilkins and Ouchi, 1983). Research on strategic decision making has shown that different managers may interpret identical events as opportunities or threats and that these interpretations, in turn, are related to the actions taken (Dutton and Jackson, 1987). Cultures also contribute schemas and scripts that can affect performance by providing preexisting ways of understanding what is occurring, how to evaluate it, and what sequences of actions are appropriate to the situation (Lord and Foti, 1986; Wilkins and Ouchi, 1983). Siegal and sussman (2003) asserted that social interaction which surrounds knowledge adoption and helps to integrate social construction and social presence can actually explain information sharing process. Their studies interpreted information as a factor which is embedded in a social context that establishes both information interpretation and its sharing process.

Organizational culture is a complex notion to study, develop and scrutinize. In today's research field of organizational behavior and management, there exists extremely inadequate quantity of empirical researches that discovered exclusively the affiliation between organizational culture and employee productivity which results from effective employee performance. Researches stroked the link between some phases of organizational culture and their consequences that affect employee performance and as a result affect productivity (Mathew, 2007, Trice and Beyer, 1984; Hofstede, Neuijen, Ohayv and Sanders, 1990). After a long era of research on organizational culture, scholars have established abundant links between organizational culture and organizational employee performance and productivity. Unlike previously, today researchers believe that organizational culture can be used for competitive advantage, effective employee performance and productivity (Tharp, 2009). Researchers like Peters \& Waterman (1982); Sadri \& Lees (2001) and Deal \& Kennedy (1982) and Thompson (2002) stated that strong organizational culture is a primary determinant in creating better organizational performance and sustained competitive advantage.

As culture differs from country to country and organization to organization, proposed theories often become problematic when they attempt to model the actual detail and richness of real organizations because of the complexity of interrelationships between organizational processes (Hofstede, 1990). Researchers often fail to isolate and measure many important organizational variables that are needed for theoretical background checking. Clearly, concerns should be raised on quantifying and measuring the conceptualization of organization cultures characteristics but it also leads to research possibility as well (Hofstede 1990, Mackenzie 1986, Schein 1990). Although there are a few inconsistencies in the literature, previous theoretical articulations about organizational culture and its impact on employee performance provide some crucial underpinning to test the hypothesis that information about organizational culture can be an important indicator in explaining an organization's level of productivity. Researchers like Hofstede (1990), Rousseau (1990), Smircich (1983) and Louis (1983) admit that organizational culture is holistic and socially constructed by the members of the organization and some visible features can be measured about the influences on an organization's employee performance. From numerous "culture surveys" it have been claimed that employee performance can be improved by developing and creating certain kinds of organizational cultures (Sackman and Bertelsman, 2006 and Denison, 1990,). It can be inspected that although some aspects of organizational culture have been scrutinized for their productivity, as in-depth analysis of the various aspects of organizational culture is absent in such researches (Mathew, 2007). Most of the studies cited earlier in Bangladesh on organizational culture and employee performance were not empirical. To date empirical efforts, few have explored the relationship between culture and other organizational variables. Current research is first in nature to analyze on the effectiveness of organizational culture on the employee performance and productivity of telecom industries in Bangladesh context. Being the fastest growing sector of Bangladesh, its organizational culture has lots of potential in enhancing employee performance and productivities.

\section{Methodology}

This paper is concerned with the relationship between organizational culture and its performance. As discussed 
before, the organizational culture stands out as one of the most important variables for companies' sustainable performance and competitive advantage (Madu, 2007). To construct the methodology, the paper has employed qualitative approach. Initially the paper has identified the critical aspects of corporate culture and its characteristics which influence the employee performance. Through in-depth interview, the paper has developed the essential cultural theme of the organization and its relationship with performance.

In-depth interviews were conducted in GP, the biggest cellular operator in Bangladesh with more than 32 million subscribers. It is a joint venture enterprise between Telenor (55.8\%) and Grameen Telecom operation (34.2\%). A total of 34 interviews were conducted in Grameenphone. Participants included top level, mid level and operational level employees. Along with human resources department, the paper has carried out interviews in other relevant departments such as marketing, finance, regulation affair, corporate affairs, government and strategic relations, business and societal relations, and strategy and planning. The researcher interviewed employees during their convenient times. The researcher also attended some corporate social events and dinners to get an understanding of organizational culture. During these events, the researcher noted down the significant observations, comments and insights of the employees. After data collection, the paper has accumulated all the information in structured standing to weigh significance of each record. Main objective in this phase is to locate down all the fundamental elements of GP's organizational culture that have impacted on corporate performance. These factors of organizational culture then cross checked with existing literature and critically evaluated the factors.

\section{Discussion}

GP, as a public limited company, the board of directors or top management of the company has a crucial role to play in fulfilling the stakeholders' welfare under the domain of the organizational culture. The organization itself maintains veracity in its pursuit of global standards. The top management is accountable for maintaining a culture that holds clear and transparent policies and procedures. Human resource committee of GP is elected by the GP's board of directors and the key influencers and shaped by the organizational culture and values. The role of human resource department is vital to influence the culture of the organization. The performance of employees is maintained and manipulated via motivation, rewards and codes of conduct. Regular meetings and open discussion take place in the organization to neutralize conflict, improve organizational culture and promote open learning.

The paper has approached the interview participants from the top management to the operational level employees to develop a broader understanding about the contemporary culture in the organization. Clearly the top management has a wider vision of the company and pursues employees to transform the vision into action. Top management believes that the culture can be influenced through aligning thoughts of the employees (Davenport, 1993 \& Satfold, 1998). Employees at the operational level explains culture through a generalized view suggesting that culture is the attitude that people develop by doing their daily work (Hofstede, Neuijen, Ohauv and Sanders, 1990 and Pettigrew, 1990; Martins and Terblanche 2003). Culture helps employees to direct their ideas towards the set of principles developed by GP; such culture is similar to the beliefs of Schein (1990). Since GP's culture reflects top down hierarchical structure, top managers have a better understanding of the link between culture and performance than employees at operational level. However, the results are consistent with Peters and Waterman (1982); Deal and Kennedy (1982) \& Athos and Pascale (1981) that identified the connections between culture and performance. Understanding the link is vital to identify the performance issues. GP has clear benchmarks through which performance is measured and rewarded. Earlier, scholars in the same line of thought used existing approaches for measuring culture, such as the organizational culture profile (Klein et al., 1995) and the competing values framework (Zammuto \& Krakower, 1991; Cameron \& Freeman, 1991; Chang, 1996; and Yeung, Brockbank, \& Ulrich, 1991).

GP explains its culture as a part of the operational activity of its business. The culture of GP is influenced by the norms and values of Bangladesh and is dependent on the macro environment that the organization operates in. GP's employees consider the norms, behaviors and values of the organization as fixed culture that they need to follow. Top management displays strength in upholding the rules and regulations of the organization and adds to the strong culture. If the rules and regulations of an organization are strongly defined, it can promote better employee performance and productivity. Therefore, in GP the rules and regulations for the mid level management and the employees are considered as culture. The rules and regulations of GP initiate culture for the organization and consequently it enhances employee performance and productivity. From the interviews and other research methods it has been seen that GP considers performance factors to be the attributes of individual workers. Employees are treated as assets with expected performance outcomes. Employees generally find substance in factors that directly affect performance; attributing the availability of GP's resources at their 
disposal as a sign of empowerment. Strong organizational culture builds up strong organizational commitment and higher morale which contribute to elevated efficiency and heightened performance and productivity (Furnham \& Gunter, 1993). Values alone are merely a reflection of underlying cultural assumptions. Schein (1994) described that the value setup is a social norm that identify rules or innovates specific cognitive approaches to people's interaction methods. As a matured company as GP is, the ideas of values exist within each employee. This paper has identified considerable adherence to organizational culture within every GP employee in the scope of the paper. An experienced organization like GP defines its organizational goals and strategic objective to meet its vision for the organization's future (Mintzberg, 1987; Ohmae, 1982; Hamel and Prahalad, 1994).

Excessive competitive culture has been observed in GP. For example, operational goals such as sales targets, profit margins, etc. that lead to department attributed achievements (departments like finance, marketing, public relations, etc); which hinders the execution of organizational goals. Since every department has prioritized goals, conflict within the departments may hinder in the process of attaining organizational goals. This competitive state, while effective at times, may lead to confusion towards employees' focuses. If a sense of unhealthy competition arises between divisions, they will tend to undermine cooperation within the organization and adversely affect the overall plan the company had. In relation to the literature, the paper finds that individuals may hold similar values, interpret situations and events similarly (Meglino, Ravlin, \& Adkins, 1989) which can reduce uncertainty (Schein, 1985), role ambiguity, and conflict (Fisher and Gitelson, 1983), allow for the accurate prediction of other's behavior (Kluckhohn, 1951), and make successful interpersonal interactions more likely (Meglino et al. , 1989). In practice, it can be stated that everyone in the organization is aware of the prime objectives. The task division and the information transparency can be considered to a level of division of labor in order to improve productivity. This may also be an attributable element within the strong culture to aid the performance (Furnham \& Gunter 1993).

The division of the shared objective creates a situation where each participant can focus on specific goals. This will mean controlled freedom for individuals who can also visualize the big picture. To put this into a scenario, consider the operation of a call-center in GP, as it is an integral part of GP's operation. There is defined primary goal the call center aims to achieve; which can be summed to providing the highest amount of customer service in the least amount of time. The call operator's goals can satisfy each of his/her customers, whereas the manger can have his goals set as making sure there are no major problems that can interrupt the flow of each operator. The set goals maybe different but the final goal remains the same. The employees in GP are confident about the management system and believes that every set goals they are given are well strategized. This rationality has been supported by the view of authors like Saphier \& King (1985); Reynolds (1986); Sashkin (1996); Tucker \& McCoy (1988).

As an organization, GP maintains a richly integrated benchmark of employee performance factors. These factors are mainly related with the organization's goals and objectives and reflect the organization's strategic planning. Sincerity of the employees, dedication toward the job, respect for the organization, respect for the job, cooperation toward fellow workers and so on. The environment of the organization helps the employees to perform fittingly and meet the performance levels expected of them. GP seeks to uphold an environment that enhances organizational culture and helps to meet the benchmarks of employee performance factors.

When established in 1996; GP was the market leader and its goal was to make a position of the organization in the minds of the people. But now, as the market approaches complete saturation, the organizational goal is somewhat altered to make the organization a strong competitor within the industry. As stated in its mission and vision, GP aims to connect the whole country under a single network. While this goal is still in focus, the competitive scenario has brought on alterations to the operating systems, vis-à-vis, and alterations in the contemporary culture. The organizational culture of GP is related to its goals and objectives and often takes new form with changes in rules, regulations and policies of the organization. The organization correlates its culture and targeted goals and considers the clear relationship between its organizational culture and the goals and objectives as a major factor behind the organization's success. GP has an effective organizational culture and the culture itself is contributing to employee effective performance and efficient productivity. Furthermore, GP's employees appear satisfied with its culture as the organization is successfully operating in its respective area throughout the country. As employee performance depends on employee satisfaction, GP can be believed to have successfully attained employee satisfaction through employee performance.

GP, the leading name in mobile telecommunication sector in Bangladesh, provides a strongly unifying environment for its employees and it makes the best attempt to tie the employees within a singular inseparable network. Thus, the expected goal of the organization becomes a shared goal of all the related people with the 
organization. In today's competitive corporate world an organization needs to guide the behavior pattern of the organization and its people's action to attain desired strategic position. GP has attained its strategic position and has become a dominant force in the industry. GP strongly considers the culture of the organization as a strong influencer behind its attainment and through this culture relates its employees with the goals and objectives of the organization.

In GP, a friendly and supportive working environment is provided for the employees. It ensures that the rules and regulations of the organization are well defined and not a burden to its employees. It is important that employees feel motivated to follow the rules and regulations and are not being forced. This leads to employee satisfaction and positive associations with the organization, management and respective individual positions. The rules and regulations are considered an inalienable part of the culture. As the employees are satisfied with the rules and regulations, they are also satisfied with the culture the organization provides. GP has a satisfactory organizational culture for its employees and this culture creates motivation for high standards of performance. Organizational culture of GP imparts a sense of satisfaction among its employees. While the benefits the organization provides to the employees, both tangible and intangible, add to job satisfaction. This can be proven due to the positive behavior of employees and the business outcomes. But does it affect organizational performance? The answer is yes, and on an equivalent scale. The results suggest the positive traits leading to positive results. GP with access to large capital, thus ensuring employee satisfaction becomes relatively easy via monetary rewards in even the highest levels of the organization. The GP culture however takes measures to avoid such a circumstance by resorting to altered strategies to improve the situation.

Innovation is key thrust at GP that takes to the forefront of the industry. At the introduction stage, the organization used to practice radical innovations and captured the market within a short period of time. The contemporary market however is well defined and highly competition allowing for little room for untested concepts or radical innovation. Thus, the organization recently used open innovation and creativity as a weapon to compete in this highly saturated market and to hold their current strategic position instead of chasing after new ideas. At this juncture, GP is imparting system upgrades and incremental innovation. The organizational culture of GP has a strong influence towards the innovation; by creating new functionality in assembling parts in new ways and bringing technical improvements and extending the applications of its previously done radical innovations. The organizational culture of GP needs to have a positive impact on innovation and creativity for the purpose of its business environ and maintain its current position in the market. GP has been a successful operator in the market for more than decade now and it can be said that its product is reaching the maturity stage. The organization has reached a stage where it encourages innovation. The innovation GP tends to create in its employees is through highly cross-functional activities. As Ilgen \& Pulakos (1999) pointed out, the emerging innovation and creativity make organization active in dealing with changes. Innovations are not always apparent directly, the way GP culture affects innovation and creativity is affecting more passive functions of the company. Authors like Martell (1989), Schuster (1986), Phesey (1993) and Ahmed (1998) in their works have highlighted on the organization cultures influence over the creativity and innovation of employees which ultimately inspire organizational performance.

The ability to change the system as per situational demands can provide higher value to its customers; thus can produce better performance (Senge, 1990; Stalk, 1988; Nadler, 1990). In addition to that the different layers of control, the flow of information had a well coordinated process which creates a healthy communication process for the company. Due to the flexibility that is present in the GP culture; quick innovative ideas could be applied without disorder. From the discussions so far it is obvious that GP holds a strongly satisfying culture for relevant stockholders. This culture initiates employee satisfaction and effective employee performance. Effective employee performance and productivity have resulted mainly from motivation and the opportunities provided by the organization. Leadership is another core factor of organizational culture.

In any organization the main feature of knowledge management is a focus on organizational objectives; these include employee performance and productivity, competitive advantage, innovation, sharing of knowledge and skills, and integration, leading to the improvement of the organization. For an effective knowledge management that can support the successful processes of an organization, the system should be supported by the organization's culture and cultural factors. GP is a large capital invested and expensive technology based organization and knowledge management plays a key role. At GP, knowledge management is crucial to the organization's competitive advantage and the cultural factors heavily affect the knowledge management. The factors of knowledge management such as employee performance, productivity, and competitive advantage are highly influenced by the organizational culture of GP. Another crucial finding of the research is the encouragement of GGP to its knowledge workers. Due to its technological business mannerism GP employs 
numerous knowledge based employees whose performance is based on creativity and innovation. GP rewards innovation and creativity, periodically holding different intra-company competitions among employees.

How the employees perceive the organization they work for gives a perspective of how culture govern the daily lives of the employees. To start with structure of the organization is mostly professed to be very functional. The common dysfunctional organizational traits such as outgrowth, over managed and the passive-aggressive builds are said to be absent. GP is a large company having complexity to be controlled is a realistic issue. The problem roots from a small number of people being in charge of the entire span of control. The organizational hierarchy (Annual Report- Grameenphone, 2011) suggests the active management process is divided into six division head who receive their orders from the chief executive officer. This span of control so far has been effective in keep the company at track and the success of the company is testament of that. The interview candidates when asked if culture has a role in affecting the structure hinted that the chain of command works in harmony due to the mutual respect for the management. Many organizations place top most priority on collaboration as a tool of better decision-making and overall output and these very organizations are likely to foster teamwork and organize tasks around groups of people rather than individuals (Tucker \& McCoy, 1988; Denison \& Mishra, 1995; Reynolds, 1986; Kilmann \& Saxton, 1991; Quinn \& Rohrbaugh, 1983; Sashkin \& Kiser, 1993).

Through this research it is seen that GP is holding its strategic position and playing as a market leader from the very beginning of their business operation. The organization's employee performance and productivity (which is often used arbitrarily to explain extensive matter starting from efficiency and effectiveness to improvement (Stannack, 1996, p. 38) that results from its strong and encouraging organizational culture are key contributors to GP's status. GrameenPhone which is renowned for its employee satisfaction reserves an employee retention policy. From the interviews and other research methods it has been inferred that it is not the specific cultural attributes rather than the collective amalgamation of these attributes that aid employee satisfaction. Organizational success is based on the participation and one of the primal objectives of any organization is to create an organizational citizenship or shared vision (Senge, 1990). The cultural attributes aid GP in setting up an organizational citizenship among employees; which is accompanied by a sense of mission and purpose (Lipman-Blumen and Leavitt, 1999). From the research it has been mapped that GrameenPhone considers the employees of the organization as assets that are inseparable parts of the organization. Consequently, the employees work for the organization, not because they are committed to do so, but because they consider themselves as a part of the organization; accepting the success or failure of the organization as their own. One of the primal focuses of GrameenPhone is motivation and studies have proven that beliefs about what motivates employees are basic to the organizational behavior (Locke, 1978; Maslow, 1943; Vroom, 1964 and Beyer, 1998; Schein, 1992). Corporate values of GrameenPhone played an important role of inciting motivation. According to Hofstede (1980) the values of organization lies within the heart of it. Qualitative research brings evidence to GrameenPhone setting high standards when it comes to the aspect of 'Values'.

\section{Conclusion}

The paper demonstrated that numerous attributes of organizational culture have significant positive influence over the performance of organization. The paper has mapped out different cultural aspects of organizations as well as showed the vital relationship between culture and performance. The qualitative research facilitated the paper with its robust and in-depth observations. Through robust and in-depth observations, the paper explained how employees' beliefs, norms, gestures and all relevant aspects of organizational culture impacted on firm's performance. The findings of the paper significantly demonstrate both positive and negative mannerism of culture which has significant consequences on employees as well as firms performance. The paper has covered an extensive range of cultural traits which include from behavioral aspects to gestural attributes. The paper also asserts that organizational culture is an open system approach which has interdependent and interactive association with organizations performance. The sophisticated and extensive nature of the paper would add value to organization studies discipline by providing an important qualitative perception towards organizational culture and performance and would initiate further discussions to create an effective framework between organizational culture and its impact on performance. However, the paper might have some limitations. For instance, outcomes of the research are drawn by observation, the thoughts and perceptions of the different managerial level of the organization. Therefore, this process might be affected by some perceptual errors of top level personnel of the organization. Nevertheless, the paper contributes to the field of management research in the context.

\section{References}

Abbasi, S. M., \& Hollman, K. W. (2000). Turnover: The real bottom line. Public Personnel Management, 29 , 
333-342.

Akin, G., \& Hopelain, D. (1986). Finding the culture of productivity. Organizational Dynamics, 14(3), 19-32.

Alvesson, M. (1989). Concepts of organizational culture and presumed links to efficiency. International Journal of Management Science, 17(4), 323-33.

Argyris, C. (1964). Integrating the individuals and the organizations. New York: Wiley.

Armstrong, M., \& Baron, A. (1998). Performance management: The new realities. London: Institute of Personnel and Development.

Barney, J. B. (1986). Organizational Culture: Can it be a Source of Sustained Competitive Advantage? Academy of Management Review, 11, 656-665.

Becker, B., \& Gerhart, B. (1996). The impact of human resource management on organizational performance progress and prospects. Academy Management of Journal, 39(4), 779-802.

Becker, B., Huselid, M., Pickus, P., \& Spratt, M. (1996). Crisis and opportunity: the two faces of human resource management in the 1990s and beyond. Paper presented at the Human Resource Management ESRC Seminar Series, London.

Blaikie, N. (1991). A critique of the use of triangulation in social research. Quality and Quantity, 25, 115-136.

Boniface C. Madu. (2012). Organizational culture as driver of competitive advantage. Journal of Academic and Business Ethics, 5.

Campbell, D. T. (1977). On the nature of organizational effectiveness. In Goodman, P. S., \& Pennings, J. M. (Eds.), New Perspectives on Organizational Effectiveness (pp. 13-55). Jossey-Bass, San Fransisco, CA.

Campbell, J. P. (1990). Modeling the performance prediction problem in industrial and organizational psychology. In M. D. Dunnette \& L. M. Hough (Eds.), Handbook of industrial and organizational psychology, 1, 687-732. Palo Alto: Consulting Psychologists Press.

Campbell, J. P. (1999). The definition and measurement of performance in the new age.

Campbell, J. P., Gasser, M. B., \& Oswald, F. L. (1996). The substantive nature of job performance variability. In K. R. Murphy (Ed.), Individual differences and behavior in organizations (pp. 258-299). San Francisco: Jossey-Bass.

Campbell, J. P., McCloy, R. A., Oppler, S. H., \& Sager, C. E. (1993). A theory of performance. In N. Schmitt \& W. C. Borman (Eds.), Personnel Selection in Organizations (pp. 35-70). San Francisco: Jossey-Bass.

Chan K. W., \& Mauborgne, R. (1999). Strategy, value innovation, and the knowledge Economy. Sloan Management Review, Spring, 41-51.

Chatman, J. A. (1989). Improving interactional organizational research: A model of person organization fit. Academy of Management Review, 14, 333-349.

Daft, R. L., \& Weick, K. E. (1984). Toward a model of organizations as interpretation systems. Academy of Management Review, 9(2), 284-295.

Dale, B. G. (2003). TQM: an overview. In Dale, B. G. (Ed.), Managing Quality, Blackwell ( pp. 3-30). Oxford.

Deal, T., \& Kennedy, A. A. (1982). Corporate culture: Rites and rituals of organizational life. Reading, MA: Addison-Wesley.

Delaney, J. T., \& Huselid, M. (1996). The impact of human resource practices on perceptions of organizational performance. Academy of Management Journal, 39, 949-969.

Denison, D. R. (2000). Organizational culture: Can it be a key lever for driving organizational change. In S. Cartwright \& C. Cooper (Eds.), The Handbook of Organizational Culture. London: John Wiley \& Sons.

Denison, D. R., \& Mishra, A. K. (1995). Toward a theory of organizational culture and effectiveness. Organization Science, 6(2), 204-223.

Denison, D. R. (1990). Corporate Culture and Organizational Effectiveness. New York, NY: John Wiley \& Sons.

Denison, D. R. (1996). What is the difference between organizational culture and organizational climate? A native's point of view on a decade of paradigm wars. Academy of Management Review, 21(3), 619-54.

Denison, D. R., \& Mishra, A. K. (1995). Towards a theory of organizational culture and effectiveness. Organisation Science, 6(2), 204-23. 
DiMaggio, P. J., \& Powell W. W. (1983). The Iron Cage Revisited: Institutional Isomorphism and Collective Rationality in Organizational Fields. American Sociological Review, 48, 146-160.

Druckman, D., Singer, J. E., \& Cott, V. (1997). Enhancing Organizational Performance. National Academy of Sciences, U.S.A.

Druckman, D., \& Bjork, Robert A. (1994). Learning, Remembering, Believing: Enhancing Human Performance. Washington, D.C.: National Academy Press.

Dutton, J., \& Jackson, S. (1987). Categorizing strategic issues: Links to organizational action. Academy of Management Review, 12, 76-90.

Ehtesham ul M., \& Muhammad Shakil A. (2011). Impact of Organizational Culture on Performance management practices in Pakistan. Department of Management Sciences, COMSASTS Institute of information Technology, Islamabad, Pakistan.

Emery R. E., \& Trist E. L. (1960). Social Technical System. In C. W. Churchman \& M. Verhulst (Eds.), Management Science Model and Technique (Vol. 2, pp. 83-97). Elmsford, NY: Pergamon Press.

Feldman, M., \& March, J. (1981). Information as Signal and Symbol. Administrative Science Quarterly, 26, 171-186.

Ferris, G. R., Arthur, M. M., Berkson, H. M., Kaplan, D. M., Harrell-Cook, G., \& Frink, D. D. (1998). Toward a social context theory of human resource management-organizational effectiveness relationship. Human Resource Management Review, 8, 235-264.

Fisher, C. D., \& Gitelson, R. (1983). A meta-analysis of the correlates of role conflict and ambiguity. Journal of Applied Psychology, 68, 320-333.

Flick, U. (2009). An introduction to qualitative research (4th ed.). London: Saga Publications.

Furnham, A., \& Gunter, B. (1993). Corporate Assessment: Auditing \& Company Personality. Rout ledge. London.

Gardner, W. L., \& Schermerhorn, J. R., Jr. (2004). Unleashing individual potential: Performance gains through positive organizational behavior and authentic leadership. Organizational Dynamics, 33, 270-281.

Gordon G., \& Christensen E. (1993). Industry inlluences on the relationship between management culture and performance. Paper presented at the national meeting of the Academy of Management. Atlanta, GA.

Gordon G., \& Cummins W. (1979). Managing management climate. Toronto, Canada, Lexington Books.

Gordon G., \& DiTomaso N. (1992). Predicting corporate performance from organizational culture. Journal of Management Studies, 29, 783-798.

Guest, D. E. (2001). Human resource management: when research confronts theory. International Journal of Human Resource Management, 12(7), 1092-106.

Hellriegel, D., \& Slocum, J. M. (2007). Organizational Behavior. South- Western, U.S.A.

Hofstede, G. (1980a). Culture's consequences: international differences in work related values. Beverly Hills, CA: Sage.

Hofstede, G. (1980b). Motivation, Leadership and Organization: do American theories apply abroad? Organizational Dynamics, 9(1), 42-63.

Hofstede, G., Neuijen, B., Ohayv, D. D., \& Sanders, G. (1990). Measuring organizational cultures: a qualitative and quantitative study across twenty cases. Administrative Science Quarterly, 35(2), 286-316.

Ilgen \& Pulakos E. D. (2001). The changing nature of performance. Implications for staffing. In E. Schmitt, W. C. Borman, \& Associates (Eds.), Personnel selection in organizations (pp. 35-70). San Francisco: Jossey-Bass.

Jossy Mathew. (2007). The relationship of organizational culture with productivity and quality: A study of Indian Software organizations. Cardiff Business School, Cardiff University, Cardiff, UK.

Javidan \& Dastmalchian. (2009). Cultural Influences on Leadership and Organizations: Project GLOBE. In Mobley, W. H., Gessner, M. J., \& Arnold V. (eds.), Advances In Global Leadership (pp. 171-233.). JAl Press: Greenwich CT.

Johnson, G. (1992). Managing Strategic Change - Strategy, Culture and Action. Long Range Planning, 25(1), 28-36. 
Jick, T. D. (1979). Mixing qualitative and quantitative methods: Triangulation in action. Administrative Science Quarterly, 24, 602-611.

James G. M., \& Robert I. S. (1997). Organizational Performance as Dependent Variable. Scandinavian Consortium for Organizational Research.

Kandula, S. R. (2006). Performance management. New Delhi: Prentice Hall of India private limited.

Kelly, R. (1990). The Gold Collar Worker- Harnessing the Brainpower of the New Workforce. Addison-Wesely, Reading, MA.

Kopelman, R. E., Brief, A. P., \& Guzzo, R. A. (1990). The role of climate and culture in productivity. In Benjamin, S. (Ed.), Organizational Climate and Culture (pp. 282-318). Jossey-Bass, San Francisco, CA.

Khanna, T., \& Palepi, G. (2004). The evolution of concentrated ownership in India: broad patterns and a history of the Indian software industry. Working Paper No. 10613, national Bureau of Economic Research, Cambridge.

Khatri, N. (2000). Managing Human Resource for Competitive Advantage, A study of Companies in Singapore. International Journal of Human Resource Management, 11(2), 336-365.

Klein, A. (1996). Validity and reliability for competency-based systems: reducing litigation risks. Compensation and Benefits Review, July/August, 31-7.

Kotler, P., \& Keller, K. L. (2006). Marketing management (12th ed.). Prentice-Hall: Upper Saddle, River, New Jersey.

Kotter, J. P., \& Heskett, J. L. (1992). Corporate Culture and Performance. New York: Free Press.

Kozlowski, S. W. J., \& Klein, K. J. (2000). A multilevel approach to theory and research in organizations: Contextual, temporal, and emergent processes. In K.J. Klein \& S. W. J. Kozlowski (Eds.), Multilevel theory, research, and methods in organizations (pp. 3-90). San Francisco: Jossey-Bass.

Krefting, L. A., \& Frost, P. J. (1985). Untangling Webs, Waves, and Wildcatting: A Multiple-Metaphor Perspective on Managing Culture. Organization Culture. Beverly Hills, CA: Sage.

Kristen M. W., \& Ann H. H. (2006). When coworkers and managers quit: the effects of turnover and shared values on performance. Journal of Business and Psychology, 21, 103-126.

Kristof, A. L. (1996). Person-organization fit: An integrative review of its conceptualizations, measurement, and implications. Personnel Psychology, 49, 1-49.

Legge, K. (1994). Managing Culture: Fact or Fiction. In Sisson, K. (ed.), Personnel Management: A Comprehensive Guide to Theory and Practice in Britain (pp. 397-433). Oxford: Blackwell.

Leopold, J., Lynette, H., \& Watson, T. (1999). Strategic human resourcing-principles, perspectives and practices. Financial Times, Pitman Publishing, London.

Levitt, B., \& March J. G. (1988). Organizational Learning. Annual Review of Sociology, 14, 314-340.

Lewis, D. S. (1994). Organizational Change: Relationship Between Reactions Behavior and Organizational Performance. Journal of Organizational Change Management, 7(5), 41-55.

Likert, R. L. (1961). The human organization. NY: McGraw-Hill.

Lim, B. (1995). Leadership \& Organization Development Journal, 16(5), 16-21. MCB University Press Limited.

Liviu Ilies., \& Cornia Gavrea (2008). The link between organizational culture and corporate performance- an overview. Annals of Faculty of Economics, 4(1), 322-325.

Locke, P., \& Latham G. (1990). A Theory of Goals amd Performance. Englewood Cliffs, NJ: Prentic Hall.

Lord, R. G., Foti, R. J., \& DeVader, C. L. (1984). A test of leadership categorization theory. Organizational Behavior and Human Performance, 34, 343-378.

Luthans, F, (2003). Positive organizational behavior (POB). In R. M. Steers, L. W. Porter, \& G. A. Begley (Eds.), Motivation and leadership at work (pp. 187-19). New York: McGraw-Hill.

Machin, S., \& Stewart, M. (1996). Trade unions and financial performance. Oxford Economic Papers, 48(2), 213-41.

Magee, K. C. (2002). The impact of organizational culture on the implementation of performance management. Doctoral dissertation. 
Martin, E. C. (2000). The influence of organizational culture on creativity and innovation in a university library. Mlnf dissertation, University on South Africa, Pretoria.

Martin, E. C., \& Terblanche F. (2003). Building organizational culture that stimulates creativity and innovation. European Journal of Innovation Management, 6(1), 64-74.

Martin, J. (1992). Cultures in organizations: Three perspectives. New York: Oxford University Press.

Martin, J., Frost, P. J., \& O’Neil, O. A. (2006). Organizational culture: beyond struggles for intellectual dominance. Graduate School of Business, Stanford University.

Mathew, J. (2007). The relationship of organizational culture with productivity and quality: A study of Indian software organizations. Employee Relations, 29(6), 677-695.

McGregor, D. (1960). The human side of enterprise. NY: McGraw-Hill.

McGuire, J. B. T. S., \& Branch B. (1990). Perceptions of Firm Quality. A cause or Result of Firm Performance. Journal of Management, 16, 167-180.

McKercher, B. (2000). Triangulation- a methodological discussion. International Journal of Tourism Research, 2, 141-146.

Mintzberg, H. (1979). Structures in Fives, Designing Effective Organizations. Prentice-Hall, Englewood Cliffs, NJ.

Miranda, S. M., \& Saunders, C. S. (2003). The social construction of perspective on information sharing. Information Systems Research, An alternative motivation, and development. San Francisco: Jossey-Bass.

Mishra, J., \& Morrisery M. A. (1990). Trust in employee employer relationship: a survey of West Michigan managers. Public Personnel Management, 19(4), 443-61.

Morgan, G. (1988). Riding the Waves of Change: Developing Managerial Competences for a Turbulent World. London: Jossey-Bass.

Nadler, D., \& Tushman, M. (1988). Strategic Organization Design. Glenview IL: Scott. Foresman.

Newell, S., Robertson, M., Scarbrough, H., \& Swan, J. (2002). Managing Knowledge Work. New York, NY: Palgrave.

O'Reilly, C. (1989). Corporations, Culture and Commitment: motivation and social control in organizations. California Management Review, Summer.

Ogbonna, E. (1993). Managing Organizational Culture: Fantasy or Reality? Human Resource Management Journal, 3(2), 42-54.

Ogbonna, E., \& Harris, L. C. (1998a). Organizational Culture: It's Not What You Think. Journal of General Management, 23(3), 35-48.

Ouchi, W. G. (1981). Theory Z, Reading. MA: Addison-Wesley.

Pascale, R. T., \& Athos, A. G. (1981). The Art of Japanese Management. Warner, New York, NY.

Patterson, M., Warr, P., \& West, M. (2004). Organizational climate and company productivity: the role of employee affect and employee level. Journal of Occupational and Organizational Psychology, 77(2), 193-216.

Peters, L. H., \& OConnor, E. J. (1980). Situation constraints and work outcomes: The influence of frequently overlooked structure. Academy of Management Review, 5, 391-397.

Peters, T. J., \& Waterman, R. H. (1982). In Search of Excellence. New York, NY: Harper \& Row.

Pettigrew, A. M. (1979). On Studying Organizational Cultures. Administrative Science Quarterly, 24, 570-81.

Porter, M. E. (1985). Competitive Advantage: Creating and Sustaining Superior Performance. New York, NY: Free Press.

Powell, T. C. (1992). Organizational alignment as competitive advantage. Strategic Management Journal, 13(2), 119-34.

Prahalad, C. K., \& Bettis, R. A. (1986). The Dominant Logic: A New Linkage between Diversity and Performance. Strategic Management Journal, 7, 485-501.

Price, L. L., Arnould, E. J., \& Curasi, C. F. (2000). Older consumers' disposition of special possessions. Journal of Consumer Research, 27(2), 179-201. 
Reed, R., \& DeFillippi, R. J. (1990). Causal Ambiguity, Barriers to Imitation, and Sustainable Competitive Advantage. Academy of Management Review, 15, 88-102.

Ritchie M. (2000). Organizational culture: An examination of its effect on the initialization process and member performance. Southern Business Review, 25, 1-13.

Sackmann, S. A., \& Bertelsmann S. (2006). Success Factor Corporate Culture. Developing a Corporate Culture for High Performance and Long-term Competitiveness, Six Best Practices. Kinndle Edition.

Schein, E. (1985). Organizational Culture and Leadership. San Francisco, CA: Jossey-Bass.

Schein, E. H. (1996). Culture: the missing concept in organizational studies. Administrative Science Quarterly, 41(2), 229-40.

Schein, E. (1990). Organizational culture and leadership. San Francisco: Jossey-Bass.

Schein, E. H. (1985). Organizational culture and leadership. San Francisco: Jossey-Bass.

Schein, E. M. (1999). The corporate culture survival guide sense and nonsense about Culture change. Josey-Bass.

Schein, E. M. (2004). Organizational culture and leadership (3rd ed.). Jossy-Bass.

Schein, E. H. (1986). What you need to know about organizational culture. Training and Development Journal, 40, 30-3.

Schein, E. H. (1990). Organizational culture. American Psychologist, 45, 109-19.

Schein, E. H. (1996). Culture: the missing concept in organization studies. Administrative Science Quarterly, 41(2), 229-40.

Schermerhorn, J. R. Jr., Gardner, W. L., \& martin, T. N. (1990). Management dialogues: Turning on the marginal performer. Organizational Dynamics, 18, 47-59.

Scholz, C. (1987). Corporate Culture and Strategy - The Problem of Strategic Fit. Long Range Planning, 25, $3-16$.

Shaw, J. D., Gupta, N., \& Delery, J. E. (2002). Voluntary turnover and organizational performance. Denver, CO: Paper presented at the Annual Meeting of the Academy of Management.

Siehl, C., \& Martin, J. (1990). Organizational Culture: a key to financial performance. In Schneider, B. (Ed.), Organizational Climate and Culture. San Francisco, Ca: Jossey-Bass.

Sivakumar, K., \& Nakata, C. (2001). The Stampede toward Hofstede's framework: avoiding the sample design pitting cross- cultural research. Journal of International Business Studies, 32(3), 555-574.

Sussman, S. W., \& Siegal. (2003). Informational Influence in organization An integrated approach to knowledge adoption. Information Systems Research, 14, 47-65.

Sutton, R. I., \& Callahan A. L. (1987). The Stigma of Bankruptcy: Spoiled Organizational Image and Its Management. Academy of Management Journal, 30, 405-436.

Tharp, B. M. (2009). Four Organizational Culture Types: Organizational Culture White Paper.

Thompson, A. A. , Strickland, A. J., Gamble, J. E. (2005). Crafting and executing strategy: The quest for competitive advantage: Concepts and cases (4th ed.). McGraw-Hill, Irwin.

Trice, H. M., \& Beyer, J. M. (1984). Studying organizational cultures through rites and ceremonials. Academy of Management Review, 9, 653-669.

Trice, H. M., \& Beyer, J. M. (1993). Studying Organizational Cultures through Rites and Ceremonials. The Academy of Management Review, 9(4), 653-669.

Van Scotter, J., Motowidlo, S. J., \& Cross, T. C. (2000). Effects of task performance and contextual performance on systemic rewards. Journal of Applied Psychology, 85, 526-535.

Verbeeten, F. H. M. (2008). Performance management practices in public sector organizations: Impact on performance. Accounting, Auditing \& Accountability Journal, 21(3), 427-454.

Watkins, K., \& Marsick, V. (1993). Sculpting the Learning Organizatio: Lessons for learning organization. San Fransisco, CA: Jossey-Bass.

Wilkins, A., \& Ouchi, W. G. (1983). Efficient cultures: exploring the relationship between culture and organizational performance. Administrative Science Quarterly, 28(3), 468-81. 
Willmott, H. (1993). Strength is Ignorance: Slavery is Freedom: Managing Culture in Modern Organizations. Journal of Management Studies, 30(4), 515-51.

Yilmaz, C., \& Ergun, E. (2008). Organizational culture and firm effectiveness: An examination of relative effects of culture traits and the balanced culture hypothesis in an emerging economy. Journal of World Business, 43, 290-306.

Yin, R. K. (2003). Case Study Research-Design and Methods. London: Saga Publications. 